\title{
Ecological Environment Evaluation of Natural Wetland and Ecotourism Development in Heilongjiang Province
}

\author{
Fuhua Xuan* \\ School of Tourism and Cuisine, Harbin Commercial University, Harbin, PR. China
}

Keywords: Ecological environment evaluation, Wetland, Ecotourism development

\begin{abstract}
River wetland, lake wetland, and marsh are the main three types of wetland widely distributing in Song-Nen plain, San-Jiang plain, Daxingan mountains and Xiaoxingan mountains. Zhalong wetland, Xingkaihu wetland and Nanwenghe wetland have been selected as the research objects in this paper, which represent marsh, lake wetland, and river wetland separately. Firstly, the paper evaluates ecological environment of different types of wetland in Heilongjiang province. The results show that ecological environment in Nanwenghe wetland is better than Xingkaihu wetland, which is better than Zhalong wetland. Secondly, environment problems in wetland ecotourism development are discussed from three aspects, poor awareness of environmental protection, lack of professional personnel, and inefficient management model. At last, development strategies are given such as strengthen protection and publicity education, strengthen the management ability, and strengthen the cultivation of wetland tourism professionals so as to improve the healthy development of ecotourism in Heilongjiang province.
\end{abstract}

\section{Present Situation of Ecotourism Development in Heilongjiang Province}

1.1 Prominent Importance. There are many distinctive and unique wetlands scenic in Heilongjiang province. For example, Zhalong wetland keeps the most perfect, the most primitive, and the most open wetland ecosystem at the same latitude area in north China. It provides ideal habitat for numerous birds and cherish waterfowl. Xingkaihu wetland, the complicated and integrated wetland ecosystem in Xingkaihu wetland, which includes nearly most of the species in Sanjiang plain, consists of lakes, forests, meadows, and rivers. It is also a giant natural gene pool and natural museum. Biodiversity in Nanwenghe wetland is so extremely rich that it nearly includes all the terrestrial biota, aquatic biota and wetland biota in primeval forest of cold temperate zone in Daxingan Mountains. It is the only one nature reserve in China which protect forest, marshes, meadows, water ecosystem and rare animals and plants in cold temperate zone.

1.2 Rich Ecotourism Scenic. The scenic in wetlands of Heilongjiang province is very beautiful with forest, river, lakes, grassland, marshes, fresh air, etc. That's the reason why it is one of the famous tourist destinations in China. For example, Xingkaihu wetland, Jingpohu wetland, San-Jiang plain wetland, Zhalong wetland, as well as other famous wetland scenic, attract many tourists abroad and domestic every year. Wetlands in Heilongjiang province provide important habitats and migrates passageway for some rare birds and beasts because of its special location. As a result, over 10,000 tourists international and domestic go to these reserves to see rare birds every year. In addition, many places are not only where important historical event take place, but also the local residential area. So the wetland culture such as history, cuisine, folklore and handicrafts are also special attractions. ${ }^{[1]}$

1.3 Obvious Tourism Effect. The number of tourist coming to wetland scenic in Heilongjiang province was up to 141.9 million, accounting for $13.3 \%$ of that of the whole province. Xingkaihu wetland and Wudalianchi hosted 1.1 million and 1.04 million. tourists in 2015 respectively, which were $12.3 \%$ and $6.12 \%$ higher than 2014. In 2015, wetland tourism in Heilongjiang received a total of 129 million tourists, an increase of $22.74 \%$ than 2014, and tourism revenue went up to 133.72 billion Yuan. Among those, the number of tourists in Daqing wetland was over 15.37 million and the tourism revenue was about 70 billion Yuan. In 2016, Jingpohu wetland, Xingkaihu wetland and Zhalong 
wetland attracted 69.01 million, 5.77 million and 400 thousand people respectively and greatly increased than ever.

\section{Ecological Environment Assessment}

2.1 Introduction of Study Area. Zhalong wetland, Xingkaihu wetland and Nanwenghe wetland have been selected as the research objects in this paper, which represent marsh, lake wetland, and river wetland separately.

The area of Zhalong wetland, Xingkaihu wetland and Nanwenghe wetland are 0.21 million hectare, 0.43 million hectare, 0.23 million hectare respectively. The survey shows that there are 16 orders, 48 families and 260 species of birds, 16 orders, 40 families and 234 species of birds, 16 orders, 40 families and 216 species of birds in Zhalong wetland, Xingkaihu wetland and Nanwenghe wetland respectively. ${ }^{[2,3,4]}$ Zhalong wetland is one of international important wetlands, but due to the imperfect laws, large-scale water conservancy project construction, industrial and agricultural wastewater discharge, the excessive development and utilization of land, human activities have affected the core area of nature reserve, resulting in rapid reduction of water area, serious degeneration of wetland vegetation, extreme eutrophication of water, sharp decline of ecological and hydrological functions. Although no introduction of a large number of species, wetland ecological system has changed. ${ }^{[5]}$ Wetland ecosystem in Xingkaihu nature reserve has been rarely affected by human activities because of the intensified management of the local government and the related departments as well as the increase of the local residents' environment protect awareness in recent years. There is no human live in the core area of nature reserve now, so Xingkaihu wetland ecosystem basically keeps the background of Sanjiang plain. Nanwenghe wetland nature reserve is located in forest region, and far from the places of human life. Although it began to develop in 1991, the forest-meadow-marsh ecosystem in the reserve is still in a state of nature, and not affected by human activities at all. At present, the water in Zhalong wetland is the moderate pollution, and belongs to IV and V class standard. ${ }^{[6]}$ Xingkaihu wetland is light eutrophication and the mild pollution. Nanwenghe wetland is far from human places and few disturbed by human, where water quality is very good. ${ }^{[7,8]}$ Due to lack of water, vegetation in the growing season reduced significantly in Zhalong wetland. And the vegetation coverage has dropped and below 30\% now. In spite of some human activities destroying the vegetation such as cut trees, cultivate wetland, the vegetation coverage in Xingkaihu wetland has changed few. Nanwenghe wetland has high vegetation coverage owing to far from live places of human. Water quality and vegetation in Zhalong wetland and Xingkaihu wetland have been destroyed by human activities. By comparison, Nanwenghe wetland lies in forest area of Daxingan mountains and has kept a state of nature. The core area of Zhalong wetland has been disturbed seriously by human activities, and that of Xingkaihu has been affected obviously. As for that of Nanwenghe wetland, it is rarely destroyed by human activities.

2.2 Assessment Method. In this method, diversity (maximum=25), representativeness (maximum=15), rarity (maximum=20), naturalness (maximum=15), suitability (maximum=15), survival threat (maximum=10) are used in the formula as follows to assess the ecological environment. ${ }^{[9]}$

$$
R_{\text {Totalscore }}=\sum_{i=1}^{2} A_{i}+B+\sum_{i=1}^{3} C_{i}+D+\sum_{i=1}^{3} E_{i}+\sum_{i=1}^{2} F_{i}
$$

In the formula (1), $\mathrm{Ai}, \mathrm{B}, \mathrm{Ci}, \mathrm{D}, \mathrm{Ei}, \mathrm{Fi}$ represent the diversity, representativeness, rarity, naturalness, suitability and survival threat respectively. On the basis of hierarchy standard widely used at present, wetland can be divided into 7 classes.

RTotal Score=91-100. The ecological environment is very good and the ecosystem is very stable.

RTotal Score $=81-90$. The ecological environment is good and the ecosystem is stable.

RTotal Score=71-80. The ecological environment is relatively good and the ecosystem is relatively stable. 
RTotal Score $=61-70$. The ecological environment and the ecosystem are general.

RTotal Score $=51-60$. The ecological environment is relatively bad and the ecosystem is relatively vulnerable.

RTotal Score=35-50. The ecological environment is bad and the ecosystem is vulnerable.

RTotal Score $<35$. The ecological environment is very bad and the ecosystem is very vulnerable.

\subsection{Assessment Index}

Table.1 Assessment of Ecological Environment Diversity in wetland

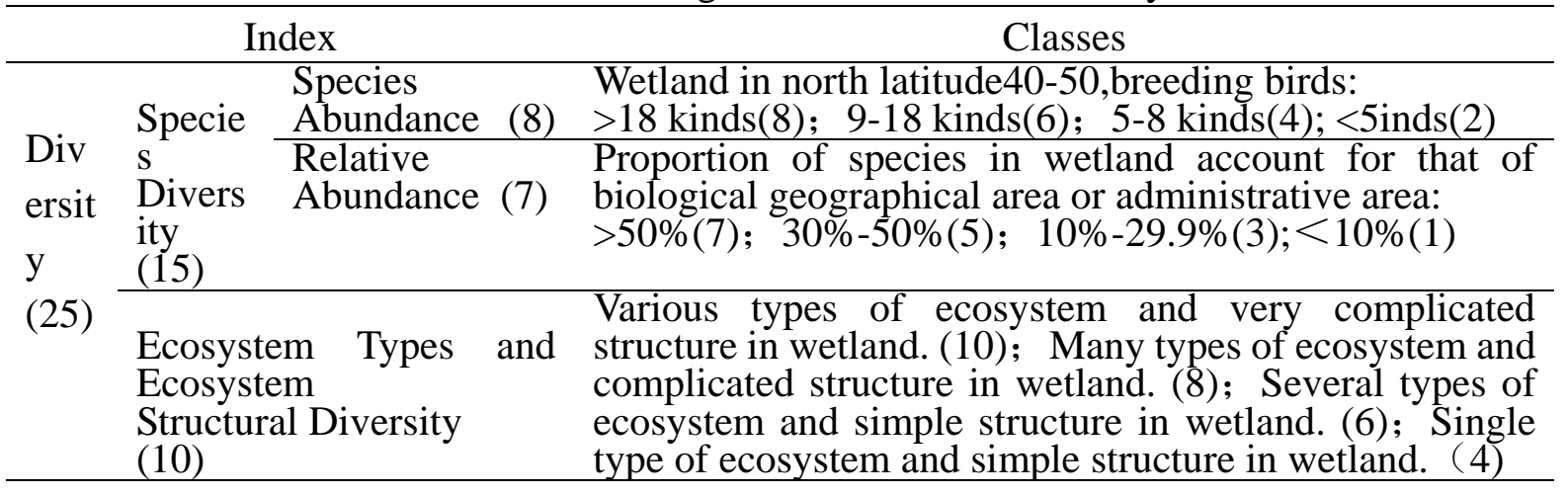

Table.2 Assessment of Ecological Environment Representativeness in Wetland

\begin{tabular}{cl}
\hline Index & \multicolumn{1}{c}{ Classes } \\
\hline Representativen & It is a representative wetland in the world or the same latitude. (15); \\
ess & region. (11); It is a representative wetland in the nation or or the \\
(15) & biogeographic province. (7); It is a common wetland.(3)
\end{tabular}

Table.3 Assessment of Ecological Environment Rarity in Wetland

Index Classes

Endangere There are endangered species of the world in wetland. (8); There are

d Species first class national protect animals or first or second class national

(8) protect plants in wetland. (6); There are second class national protect animals or third class national protect plants is wetland. (4); There

Rarit Species $\quad$\begin{tabular}{l} 
are regional rare and endangered species in wetland. (2) \\
\cline { 2 - 3 } Species in wetland can live in very few place in the world.(6);
\end{tabular}

y Distributi Species in wetland can live in few place and only can be seen in

(20) on some place or biogeographic region border.(4); Species in wetland

(6) can be seen everywhere.(2)

Ecological It is the only or important wetland in the world.(6); It is the only or

Environm important wetland in the country or biogeographic region. (4.5); It is

ent rare or important wetland in the region.(3) (4)It is a kind of common

Rarity(6) wetland.(1.5)

Table.4 Assessment of Ecological Environment Naturalness in Wetland

Index Classes

The wetland ecosystem environment is still in a state of nature and few affected by human. And the core area of the nature reserve has not been disturbed by human. (15); Although the ecosystem has been affected by human activities, the

Naturalne ecosystem structure has not changed. The core area was few destroyed by human.

ss (10); The wetland ecosystem has been destroyed seriously and the ecosystem

ss structure has changed. No introduction of a large number of species, the core area

(15) of reserve has been disturbed by human obviously. (5); The state of nature of ecosystem has been destroyed completely, and a large number of species has been introduced. The core area ecosystem of reserve has been replaced by constructed wetland ecosystem. (1) 
Table.5 Assessment of Ecological Environment of Suitability in Wetland

\begin{tabular}{|c|c|c|}
\hline & Index & Classes \\
\hline \multirow{5}{*}{$\begin{array}{c}\text { Suitability } \\
(15)\end{array}$} & Area & Wetland area is more than $400 \mathrm{hm}^{2} .(5)$; Wetland area is \\
\hline & $\begin{array}{l}\text { Suitability } \\
\text { (5) }\end{array}$ & $3400 \mathrm{hm}^{2} .(3)$; Wetland area is less than $3 \mathrm{hm}^{2} .(0.8)$ \\
\hline & $\begin{array}{c}\text { Water Quality } \\
\text { (4) }\end{array}$ & $\begin{array}{l}\text { DO Content in wetland water }>4 \mathrm{mg} / \mathrm{L}, \mathrm{pH}=6.0-8.5, \text { no lethal } \\
\text { dose of poison.(4); DO Content in wetland water }<4 \mathrm{mg} / \mathrm{L} \text {, } \\
\mathrm{pH}=6.0-8.5 \text {, no lethal dose of poison. }(3) ; \text { DO Content in } \\
\text { wetland water }<4 \mathrm{mg} / \mathrm{L}, \mathrm{pH}<6.0 \text { or }>8.5 \text {, lethal dose of } \\
\text { poison in water. }(0.6)\end{array}$ \\
\hline & Vegetation & In most time of growing season, vegetation area in wetland is \\
\hline & $\begin{array}{c}\text { Coverage } \\
(6)\end{array}$ & $\begin{array}{l}\text { more than } 70 \% \text { of wetland area. (6); In most time of growing } \\
\text { season, vegetation in wetland account for } 30 \%-70 \% \text { of wetland } \\
\text { area. (3); In most time of growing season, vegetation area in } \\
\text { wetland is less than } 30 \% \text { of wetland area.(1) }\end{array}$ \\
\hline
\end{tabular}

Table.6 Assessment of Ecological Environment of Survival Threat in Wetland

\begin{tabular}{|c|c|c|c|}
\hline \multicolumn{3}{|c|}{ Index } & Classes \\
\hline & \multirow{4}{*}{$\begin{array}{l}\text { Stabilit } \\
\mathrm{y}(6)\end{array}$} & $\begin{array}{l}\text { Species } \\
\text { Viability } \\
\text { (2) }\end{array}$ & $\begin{array}{l}\text { The main or key species in wetland do not need specialized } \\
\text { habitat, and they have very strong viability and fertility.(2); The } \\
\text { main or key species in wetland need relatively specialized } \\
\text { habitat, and they have low viability and fertility, as well as poor } \\
\text { adaptability.(1.2); The main or key species in wetland need } \\
\text { specialized habitat, and they have poor adaptability and low } \\
\text { fertility.(0.4) }\end{array}$ \\
\hline & & & Large number and high density are main features of wetland \\
\hline $\begin{array}{l}\text { Surviv } \\
\text { al }\end{array}$ & & $\begin{array}{l}\text { Stability } \\
\text { (2) }\end{array}$ & $\begin{array}{l}\text { Large number and low density, or small number and high } \\
\text { density are main features of wetland ecosystem. It is difficult } \\
\text { for minimum living population to be maintained. (1.2); Small } \\
\text { number and low density are main features of wetland } \\
\text { ecosystem. It is very difficult for minimum living population to } \\
\text { be maintained. (0.4) }\end{array}$ \\
\hline \multirow[t]{4}{*}{$\begin{array}{l}\text { Threat } \\
\text { (10) }\end{array}$} & & $\begin{array}{l}\text { Ecosyste } \\
\text { m } \\
\text { Stability } \\
(2)\end{array}$ & $\begin{array}{l}\text { The wetland ecosystem is on the top and it's structure is } \\
\text { integrated and stable.(2); The wetland ecosystem is relatively } \\
\text { integrated, fragile.(1.2); The structure of wetland ecosystem is } \\
\text { incomplete, and fragile.(0.4) }\end{array}$ \\
\hline & \multirow{3}{*}{$\begin{array}{l}\text { Huma } \\
\text { n } \\
\text { Threat } \\
\quad(4)\end{array}$} & Direct & ea of wetland has not been disturbed \\
\hline & & $\begin{array}{c}\text { Threat } \\
\text { (2) }\end{array}$ & $\begin{array}{l}\text { human activities.(2); The core area of wetland has been threat } \\
\text { by a few human activities.(1.2); The core area of wetland has } \\
\text { been threat greatly by intensive activities.(0.4) }\end{array}$ \\
\hline & & $\begin{array}{l}\text { Indirect } \\
\text { Threat } \\
\text { (2) }\end{array}$ & $\begin{array}{l}\text { The wetland is adjacent to another wetland or surrounded by } \\
\text { undeveloped habitat.(2); There are undeveloped habitat around } \\
\text { the wetland.(1.2); The wetland is surrounded by developed } \\
\text { areas.(0.4) }\end{array}$ \\
\hline
\end{tabular}

2.4 Assessment Results. According to formula (1), the results are as follows.

$$
R_{\text {Totalscore-Zhalong }}=73.2 \quad R_{\text {TotalScore-Xingkaihu }}=83.2 \quad R_{\text {TotalScore-Nanwenghe }}=86.8
$$

The results show that river wetland environment is relatively stable, and that of lake wetland, take second place, and marsh wetland environment is comparatively fragile.

\section{Environment Problems in Wetland Ecotourism Development}

3.1 Poor Awareness of Environmental Protection. Due to poor awareness of resources protection in the process of developing tourism resources, man-made destruction and constructive destruction phenomenon still occurs. Tourism image of Heilongjiang province will directly affected because of poor environmental management in many scenic spots. Although many scenic spots have invested much in manpower, material and financial resources to improve environment, the conditions 
cannot reach the standard of catering and tourism activities. Besides, the "dirty, chaotic, and poor" phenomenon in part of the scenic spots destroys the integrity of beauty enjoyment of tourists.

3.2 Lack of Professional Personnel. Wetland ecotourism requires high professional qualified practitioners. There are still some problems in the development and design of wetland ecotourism resources in Heilongjiang Province, such as lack of standardized management, industrial management, ecotourism education and training, and professionals engaged in ecotourism. In many scenic spots, few can be qualified for wetland ecotourism special tour guide, service and basic management. And most of them cannot answer the questions about ecology, plant, animal, history and others in tourism activities. And thus it cannot satisfy the ecological pursuit and the cultivation of ecological consciousness of tourists, neither carry on the correct ecotourism education to the tourists. 3.3 Inefficient Management Model. At present, the development of tourism resources in Heilongjiang province is under the conditions of multi sector co-management, which results in unclear responsibilities of various departments. The phenomenon of predatory development at the expense of resources still exists in individual place. Some of the tourism project is unreasonable, and the construction of artificial facilities and sewage facilities in place, coupled with the city industrial and domestic wastewater without treatment directly into and polluted water, causing severe damage to the tourism environment.

\section{Development Strategies of Wetland Ecotourism}

4.1 Strengthen Protection and Publicity Education. First of all, we must strengthen the public education, improve public awareness of the importance of nature reserves, and effectively protect and develop the wetland resources.

For example, we can take advantage of various activities to expand publicity and education, such as "World Wetlands Day", "Bird-loving Week", "World Environment Day", "Protection of Wildlife Propaganda Month ", etc. In that way probably we can attract the concern on wetland resources of whole society. And then, we should encourage local communities and relevant units to actively participate in the maintenance and management of wetland resources, so as to make the local residents consciously become managers and protectors of the natural environment and biodiversity.

4.2 Strengthen the Management Ability. In order to get steady and healthy development of ecological tourism, we should strengthen the hardware construction as well as software construction. The development of ecological tourism needs technological personnel with ecotourism technology, popular science personnel with wetland environment education, professionals familiar with bird knowledge, management personnel with ecological and tourism market development knowledge, etc. Therefore, it is necessary to strengthen the training of eco-tourism management personnel, improve the quality of tourism practitioners, enrich the knowledge of science and technology, and form a high-quality professional team.

4.3 Strengthen the Cultivation of Wetland Tourism Professionals. The wetland eco-tourism covers a very wide range of theory and practice including the basic operation service. Its development needs complex talents and so the comprehensive quality of the government and tourism management personnel should be improved. We should strengthen the management of the staff, regular training, increase the awareness of environmental protection, improve the professional ethics and quality of service personnel. it is recommended that public relations etiquette training should be conducted and the staff dress and service specifications should be uniformed. At the same time, tourist feedback mechanism should be established so as to accept tourists' feedback in a variety of ways.

\section{Summary}

In this paper, ecological environment of different type of wetland in Heilongjiang Province is evaluated and followed by the explanation. The result shows that ecological environment of marsh wetland is comparatively fragile, and that of lake wetland is better, and river wetland, relatively stable. 
Further, factors affecting ecological environment including poor awareness of environmental protection, lack of professional personnel, and inefficient management model are discussed in detail. At the end of the paper, some effective suggestions which related with protection and publicity education, management ability, and complex talents are put forward to improve the ecotourism development in Heilongjiang province.

\section{Acknowledgement}

This work was financially supported by the Program of Philosophy Social Science in Heilongjiang Province (16JYE05) and Program of Scientific Research Foundation for Ph.D in Harbin Commercial University (15RW20).

\section{References}

[1] J. Zou, Study on development of wetland tourism product in Heilongjiang province, Harbin: Heilongjiang University, 2012.

[2] K. Chen, Study on ecotourism development of Zhalong Nature Reserve, Harbin: Northeast Normal University, 2009.

[3] F. F. Liu, Ecological environment quality assessment in Xingkaihu Wetland Natrue Reserve, Harbin: Northeast Forestry University, 2009.

[4] J. T. Ren, Study on ecotourism resources assessment and development strategies of Nanwenghe Nature Reserve,.Harbin: Northeast Agricultural University, 2012.

[5] Z. Shu, Ecological environment assessment of Zhalong Wetland, Harbin: Northeast Forestry University, 2006.

[6] Y. Q. Wang, Wetland resources assessment and water qualitiy analysis in Zhalong Nature Reserve, Harbin: Northeast Forestry University, 2009.

[7] X. Y. Ji, T. L. Liu, J. Liu, J. M. Li, B. Q. Pan, Investigation and study on water quality and pollution condition in Xingkaihu of China, Environmental Monitoring in China, vol.29, pp. 79-84, 2013.

[8] D. X. Piao, F. K. Wang, Investigation and study on water quality and pollution condition in Xingkaihu of China.Journal of Lake Sciences, vol.23, pp.196-202, 2011

[9] C. Q. He, B. S. Cui, Z. C. Zhao, Ecological environment assessment of typical wetland in Jilin province, Chinese Journal of Applied Ecology, vol.12, pp.754-756, 2001. 